\title{
Originalism as Transformative Politics
}

Lawrence B. Solum

Georgetown University Law Center, Ibs32@law.georgetown.edu

This paper can be downloaded free of charge from:

https://scholarship.law.georgetown.edu/facpub/1746

63 Tul. L. Rev. 1599-1629

This open-access article is brought to you by the Georgetown Law Library. Posted with permission of the author. Follow this and additional works at: https://scholarship.law.georgetown.edu/facpub

Part of the Constitutional Law Commons 


\title{
ORIGINALISM AS TRANSFORMATIVE POLITICS
}

\author{
LAWRENCE B. SOLUM*
}

It is often said that a new religion brands the gods of the old one as devils. But in reality they have probably already become devils by that time.

Ludwig Wittgenstein ${ }^{1}$

One might easily paint a picture in which the central question debated in constitutional jurisprudence in recent years was whether originalism is the correct theory of constitutional interpretation. This portrait of a constitutional debate could be quite dramatic. Prominent among the figures on the originalist side stand former Judge Robert Bork, ${ }^{2}$ Chief Justice William Rehnquist, ${ }^{3}$ former Attorney General Edwin Meese, ${ }^{4}$ and scholar Raoul Berger. ${ }^{5}$ Their opponents, the nonoriginalists, include Senator Joseph Biden, ${ }^{6}$ Associate Justice William Brennan, ${ }^{7}$ and a host of constitutional scholars. The stakes of the debate seem

* Professor of Law and Rains Fellow, Loyola Law School, Los Angeles, California. I am grateful to Don Brosnan and Nancy C. Brown for detailed comments on earlier versions of this essay and to Ken Anderson for discussion of its themes. In addition, I owe thanks to the participants at the International Institute for Semiotic and Structuralist Studies held at Northwestern University in July of 1986 and especially to Bob Benson, Thomas Grey, David Hoy, Michael Moore, Michael Perry, Richard Saphire, and John Valauri. Many of the ideas presented in this essay were developed during the Institute.

1. L. WitTGenstein, Culture and VAlue 15 e (P. Winch trans. 1980).

2. See generally Bork, Neutral Principles and Some First Amendment Problems, 47 IND. L.J. 1 (1971); Bork, The Impossibility of Finding Welfare Rights in the Constitution, 1979 WASH. U.L.Q. 695; Bork, Styles in Constitutional Theory, 26 S. TEX. L.J. 383 (1985); Bork, Original Intent and the Constitution, 7 HuMaNITIEs No. 1, at 22 (1986) [hereinafter Bork, Original Intent and the Constitution]; Bork, The Constitution, Original Intent, and Economic Rights, 23 SAN DIEGo L. REv. 823 (1986) [hereinafter Bork, Economic Rights]. (1976).

3. See generally Rehnquist, The Notion of a Living Constitution, 54 TEX. L. REV. 693

4. See generally Meese, The Battle for the Constitution, 35 Pol'y REv. 32 (1985); Meese, Toward a Jurisprudence of Original Intention, 2 BENCHMARK 1 (1986); Meese, The Supreme Court of the United States: Bulwark of a Limited Constitution, 27 S. TEX. L. REV. 455 (1986).

5. See generally R. Berger, Federalism: The Founders' Design (1987); R. BERGER, GOVERNMENT BY JUdICIARY (1977); Berger, "Original Intention" in Historical Perspective, 54 GEO. WASH. L. REV. 296 (1986); Berger, New Theories of "Interpretation": The Activist Flight from the Constitution, 47 OHIo ST. L.J. 1 (1986).

6. See Wash. Post, Oct. 22, 1987, § 1, at A14.

7. See generally Brennan, The Constitution of the United States: Contemporary Ratification, 27 S. TEX. L. REV. 433 (1986). 
high: will the legacy of the Warren Court be dismantled by the Rehnquist Court's efforts to interpret the Constitution in accord with the intentions of its framers? The debate reached millions of homes through extensive media coverage of the confirmation hearings of Judge Bork. Bork's defeat might be viewed by some as the climax of the debate, and as a victory for the nonoriginalists. ${ }^{8}$

The controversy over originalism has been the focus of dozens of scholarly articles, ${ }^{9}$ and it is featured prominently in monographs on jurisprudence, ${ }^{10}$ constitutional theory, ${ }^{11}$ and legal history, ${ }^{12}$ including Michael Perry's Morality, Politics, and Law. ${ }^{13}$ Put in historical perspective, the debate between originalists and nonoriginalists might be seen as the most recent episode in a long series of debates over the role of the Supreme Court in American political life, including, for example, the debate between interpretivists and noninterpretivists or that between strict constructionists and their opponents. ${ }^{14}$

Perhaps many of the participants in the originalism debate would accept the accuracy of the portrait I have painted. No doubt many of them sincerely believe that something both practically and theoretically significant was at stake when one attacked or defended the proposition that the Constitution

8. Ronald Dworkin has made this claim. See Dworkin, From Bork to Kennedy, N.Y. Rev. Books, Dec. 17, 1987, at 36, 40.

9. See generally Alfange, On Judicial Policymaking and Constitutional Change: Another Look at the "Original Intent" Theory of Constitutional Interpretation, 5 HAST. ConsT. L.Q. 603 (1978); Brest, The Misconceived Quest for the Original Understanding, 60 B.U.L. REV. 204 (1980); Clinton, Original Understanding, Legal Realism and the Interpretation of "This Constitution," 72 IowA L. REV. 1177, 1179 n.3 (1987); Easterbrook, Legal Interpretation and the Power of the Judiciary, 7 HARv. J.L. \& PuB. PoL'y 87 (1984); Kay, Adherence to the Original Intentions in Constitutional Adjudication: Three Objections and Responses, 82 Nw. U.L. REv. 226 (1988); Maltz, The Failure of Attacks on Constitutional Originalism, 4 CONST. COMMENTARY 43 (1987); Monaghan, Our Perfect Constitution, 56 N.Y.U. L. REv. 353 (1981); Munzer \& Nickel, Does the Constitution Mean What It Always Meant?, 77 ColuM. L. Rev. 1029 (1977); Powell, Rules for Originalists, 73 VA. L. REv. 659 (1987); Powell, The Original Understanding of Original Intent, 98 HARV. L. REv. 885 (1985); Simon, The Authority of the Framers of the Constitution: Can Originalist Interpretation Be Justified?, 73 CALIF. L. REV. 1482 (1985); Tushnet, Following the Rules Laid Down: A Critique of Interpretivism and Neutral Principles, 96 HaRv. L. Rev. 781 (1983); Framers' Intent: An Exchange, 10 U. PUGET SOUND L. REV. 343 (1987).

10. See R. Dworkin, A Matter of Principle 33-57 (1985).

11. See E. Chemerinsky, INTERPRETING THE Constitution (1987).

12. See L. Levy, Original Intent and the Framers' Constitution (1988).

13. M. PERRY, MORAlity, Politics, aNd LAW (1988).

14. Valauri, The Varieties of Constitutional Theory: A Comment on Perry and Hoy, 15 N. KY. L. REV. 499, 501 (1988). 
should be interpreted in accord with the original intent of its framers and ratifiers. But the history of such debates gives us reason to pause before we agree. For example, "strict construction"-the phrase Richard Nixon used to refer to the brand of constitutional jurisprudence he preferred-is now recognized as a virtually meaningless phrase. It was never more than a rallying cry for a set of positions on a number of distinct constitutional issues; "strict construction" represents no coherent theory or principle of constitutional interpretation today.

The debate between interpretivists and noninterpretivists suffered a similar fate. Liberal constitutional scholars championed noninterpretivism as an approach to constitutional jurisprudence that might ground decisions like Griswold $v$. Connecticut, ${ }^{15}$ which seemed unconnected with particular passages in the United States Constitution. But noninterpretivism was never an accurate description of a serious position in constitutional theory; ${ }^{16}$ on the one hand, no one was denying the relevance of interpreting the constitutional text in constitutional adjudication, and on the other hand, no one was contending that the text alone was sufficient. ${ }^{17}$

The debate between originalists and nonoriginalists has begun to suffer a fate similar to these earlier debates in constitutional theory and practice. This Essay is one of a growing number of recent attempts to look back at the originalism debate now that both the critics and defenders of originalism have stated their positions and replied to arguments of their opponents. ${ }^{18}$ My conclusion, however, is unlikely to give solace to either side. As originalism has been modified and defined in reaction to nonoriginalist critiques, the originalist's position has become more and more plausible as a theory of constitutional interpretation. When I say plausible as a theory of constitutional interpretation, I mean that the most sophisticated forms of originalism provide an accurate description of the phenomenology of constitutional practice. The Constitution is interpreted in light of the purposes and concerns that animated its framing and ratification.

15. 381 U.S. 479 (1965).

16. L. LEVY, supra note 12 , at $\mathrm{xv.}$

17. See R. Dworkin, LAw's EMPIRE 359-60 (1986).

18. See, e.g., Hoy, A Hermeneutical Critique of the Originalism/Nonoriginalism Distinction, 15 N. KY. L. REv. 479 (1988); Saphire, Enough About Originalism, 15 N. KY. L. REV. 513 (1988); Valauri, supra note 14, at 499. 
As a matter of the theory of interpretation, originalism captures an important aspect of constitutional practice. But the originalists have won a Pyrrhic victory. As originalism has been clarified in response to its critics, it has gradually become more and more evident that it has no force as a critique of the kind of constitutional interpretation practiced by the Warren Court. Indeed, I will argue that originalism can serve as the basis for what Michael Perry calls "transformative politics."19

My effort to make good on this analysis of the originalism debate begins with Michael Perry's perceptive and eloquent analysis. Perry places himself in the nonoriginalist camp, but expresses his discomfort with the label he has chosen:

Although it is serviceable for present purposes, I'm not comfortable with the "originalist/nonoriginalist" terminology. There is a sense in which we are all originalists: We all believe that constitutional adjudication should be grounded in the origin-the text that is at our origin and indeed, is our origin. But there is a sense, too, in which none of us is an originalist: As Gadamer, for one, has taught us, we cannot travel back to the origin, no matter how hard we try, and we deceive ourselves if we think we can. ${ }^{20}$

Perry is right, but he does not fully realize the implications of his argument. Perry continues, "I'll happily abandon the originalist/nonoriginalist terminology as soon as someone suggests a terminology that better captures the fundamental difference animating contemporary constitutional-theoretical debate." 21 In light of the recent history of constitutional theory, it would hardly be surprising if someone did suggest a new term to capture the "fundamental difference" that Perry and others presume is at the root of the sequence of debates over "strict construction," "interpretivism," and "originalism." But Perry's basic presumption that there is a fundamental difference between his own position and that of the originalists is wrong. There is no such fundamental difference in theories of constitutional interpretation that merely awaits a more cogent expression or more apt terminology.

Part I of this Essay elaborates upon Perry's observations that, as a matter of hermeneutic theory, we all are originalists and we all are nonoriginalists; theoretically, there is no real dis-

19. M. PERRY, supra note 13 , at 152 .

20. Id. at 280 (emphasis in original).

21. Id. 
tinction between originalism and nonoriginalism. Part II provides evidence that, as a matter of practice, self-professed distinctions between originalists and nonoriginalists are even more dubious; nonoriginalists respect and rely upon originalist arguments, and originalists frequently ignore evidence of the framers' intentions. Part III applies my arguments to Perry's own theory of constitutional interpretation. Perry's view of the relationship between constitutional interpretation and prophecy illustrates a powerful but neglected insight about originalism: The Constitution has a radical potential to disturb and disrupt our constitutional practice in part because the principles that animated the framing and ratification of the Constitution can prompt us to change our own understanding of constitutional meaning.

\section{DEMISE OF THE ORIGINALIST/NONORIGINALIST DISTINCTION IN THEORY}

There is no meaningful distinction between originalist and nonoriginalist theories of constitutional interpretation. Despite the many thoughtful arguments advanced by both sides in the debate, the result has been the demise of the distinction that seemed to give rise to the controversy. My argument for this thesis will proceed in three stages. Section A argues that all constitutional theories interpret the Constitution in accord with the intent of the framers and ratifiers. In other words, originalism is ubiquitous. Section B argues for a seemingly contradictory conclusion-that originalism is impossible. No plausible version of originalism can result in decisions that accord with the intent of the framers and ratifiers. This apparent inconsistency reveals that I am using the term "originalism" in two different senses. Every interpreter of the Constitution is an originalist in the "ubiquitous" sense, and no interpreter is an originalist in the "impossible" sense. Section C deals explicitly with this ambiguity by seeking to clarify the various conceptions of originalism that have entered into the originalism debate. No plausible conception of originalism can be meaningfully distinguished from nonoriginalist positions in constitutional theory.

\section{A. The Ubiquity of Originalism}

"There is a sense in which we are all originalists," Perry 
acknowledges. ${ }^{22} \mathrm{He}$ is correct. When it comes to interpreting the Constitution of the United States, there is a very important sense in which we cannot help but interpret that document in accord with the intentions of its framers and ratifiers. In this sense, we could not evade the original understanding, even if we were to try to do so. The point that I am trying to make is most easily expressed in the vocabulary of hermeneutics-the discipline that theorizes about the interpretation of texts in general. ${ }^{23}$ But because the conceptual apparatus of hermeneutics is unfamiliar to some constitutional scholars and certainly most practitioners of constitutional law, I want to try a different strategy for introducing my point, by asking the reader to engage in a thought experiment. Imagine that the Constitution of the United States was discovered by members of a culture (call the members of this culture the Nonos) that is wholly unfamiliar with our history. If you have seen the movie The Gods Must Be Crazy, ${ }^{24}$ you might imagine that it was the Constitution of the United States, rather than an empty Coca-Cola bottle, that was dropped from a plane and discovered by members of an African tribal culture. Further imagine that despite their lack of knowledge of our history, the Nonos can understand the literal meanings of the words of the Constitution. ${ }^{25}$

The Nonos decide to adopt the Constitution as their own; they decide to run their affairs by its guidance. Why? Assume that the Nonos have recently experienced a crisis in their own form of government and they take the unexpected appearance of the Constitution as a sign from the gods of the way out of their difficulties. Immediately, the Nonos experience difficulties in interpreting their new Constitution. Some provisions are relatively clear to them, but others, quite clear to us perhaps, are simply opaque to the Nonos. Their understanding of the origin of the document guides their interpretations. To the Nonos, the Constitution is a gift from the gods; they interpret its provisions

22. Id.

23. The term "hermeneutics" has a variety of uses. See R. PALMER, Hermeneutics ch. 3 (1969) (discussing six modern definitions of hermeneutics). As I use the term in this context, hermeneutics refers to philosophical reflection on the interpretation of texts in general and to jurisprudential reflection on the interpretation of legal texts in particular.

24. (Twentieth Century Fox 1981).

25. We can either imagine that Nonos speak English (they learned long before the American Revolution from British explorers) or that they possess a translation manual, an English-Nono dictionary that gives the literal equivalent of each word and the rules for transforming English grammar into Nono equivalents. 
in light of what they believe the gods would want for their society. They know nothing, however, about our framers and ratifiers. They have never heard of James Madison or Alexander Hamilton; they are ignorant of the American Revolution, the Continental Congress, or any of the experiences that shaped the original Constitution. Likewise, they know nothing of the Civil War or of any of the events that inspired and shaped the framing and adoption of the various amendments.

What I ask you to do is to imagine a few of the many ways in which the Nonos' constitutional practice could differ from our own. Depending on Nono culture, material conditions, and traditions, I think that you will be able to envision that many provisions would likely take on meanings for the Nonos that are radically different from our understandings. If you are having difficulty imagining such divergence, I provide an example in a footnote. ${ }^{26}$ There would, of course, be superficial resemblances. For example, the Nono chieftain (President) might be selected (as perhaps she always had been) from among the elder women of the tribe, who, of course, were well above thirty-five years of age. There might even be surprising similarities in the interpretation of more ambiguous provisions. If the Nonos were in the midst of a crisis over the institution of slavery, their thirteenth, fourteenth, and fifteenth amendments might be construed in a fashion remarkably similar to the corresponding provisons of our constitution.

But in the end, I think, it is highly unlikely that Nono constitutional practice as a whole would be even remotely similar to our own. The Nonos would truly be nono riginalists. Their understanding of the Constitution would not have been pervasively shaped by a tradition that linked them to the concerns and understandings of its framers and ratifiers. The Nonos would lack the prejudices, prejudgments, and pre-understandings that thoroughly shape our interpretation of the Constitution. In a real sense they would have a different constitution.

The fable of the Nonos expresses an essential insight of

26. Imagine, for example, that Nono religious practice includes large assemblies in which individuals engage in something like what we refer to as "speaking in tongues" after imbibing a fermented beverage that is produced through the use of a press. What could be more natural for the Nonos than an interpretation of the first amendment freedoms of speech, press, and assembly as a guarantee of the right to produce and consume the sacred beverage? 
Hans-Georg Gadamer. ${ }^{27}$ Our understanding of the Constitution, Gadamer might say, is enabled by our participation in a tradition that links us to (but also separates us from) the concerns of the framers and ratifiers. For Gadamer, tradition both conditions and enables understanding. He develops this point through a critique of what he calls "the fundamental prejudice of the enlightenment," that is, "the prejudice against prejudice itself." 28 The Enlightenment was in part a rebellion of reason against tradition. For the Enlightenment, prejudice was a barrier to understanding, and tradition was an obstacle in the path of reason. In opposition to the Enlightenment's understanding of prejudice, Gadamer maintains that prejudices, literally "prejudgments," are productive of understanding. Without prejudgments about meaning, interpretation could never get started. There is no neutral vantage point from which a text can be understood independently of any tradition or prejudice. Interpreters always read a text from a historically situated vantage point that consists of prejudgments constituted by tradition, a cumulative heritage of interpretations.

In our case, it is clear that our tradition includes the actions and writings of the framers and ratifiers of the Constitution and its various amendments. It includes the events that led up to the framing of the Constitution: our colonial history, the American Revolution, and the experience under the Articles of Confederation. Our tradition includes the concerns that prompted the Constitutional Convention and the debates that led to ratification. It includes the experiences of the founding generation, and of subsequent generations that framed and ratified the amendments. Moreover, like the framers and ratifiers, our tradition includes the whole history of England and the Colonies and more particularly the history of the common law. Our common law tradition predates the Constitution itself, but the common law shaped the founding generation's understanding of the Constitution and it continues to shape our understanding.

27. For a comprehensive statement of Gadamer's theory, see H.-G. GADAMER, TRUTH AND METHOD 154 (1975). For an introduction to Gadamer's thought, see G. WARNKE, Gadamer: HeRmeneutics, TRAdition and Reason (1987). Other sources include J. Bleicher, Contemporary Hermeneutics (1980); R. Palmer, supra note 23; UNDERSTANDing AND Social INQUiRy (F. Dallmayr \& T. McCarthy eds. 1977); Phelps \& Pitts, Questioning the Text: The Significance of Phenomenological Hermeneutics for Legal Interpretation, 29 ST. LouIs U.L.J. 353 (1985), reprinted in 3 SUTHERLAND, STATUTORY CONSTRUCTION 289 (N. Singer ed., rev, ed. 1986).

28. H.-G. GADAMER, supra note 27 , at $239-40$. 
Because we stand in a tradition that has been pervasively shaped by the preconceptions, events, and concerns that led to the framing and ratification of the Constitution, we cannot help but understand that document in light of its origin. The very questions we ask in constitutional cases reflect our constitutional tradition. The interpretations that we acknowledge as possibilities and those we rule out as absurd are pervasively shaped by the origins of the Constitution. In this sense, to the extent that anyone is an originalist, we all are and must be originalists.

\section{B. The Impossibility of Originalism}

So far, my account of Gadamer's hermeneutics might give the misleading impression that his views provide unqualified support for originalism. There is, however, another very important side to Gadamer's hermeneutics that can be used as the basis for a critique of a certain conception of originalism. Gadamer's discussion of tradition should not obscure his critique of Schleiermacher's romantic hermeneutics, a position that resembles originalism. In order to understand Gadamer's critique of Schleiermacher, we need to understand the place of Schleiermacher's views in the history of hermeneutic theory. ${ }^{29}$

A thumbnail sketch of the history of hermeneutics, with an emphasis on the parallels with the theory of constitutional interpretation, can begin with Martin Luther's theory of biblical hermeneutics, a cornerstone of Protestant theology. "Luther's position is more or less the following: scripture is sui ipsius interpres. ... [T]he text of the scripture has a clear sense that can be derived from itself, the sensus literalis."

Luther's position has a parallel in the theory of constitutional interpretation: the theory called textualism or literalism holds that the Constitution can be interpreted without going beyond the four corners of the document. Luther's views had a practical aim, to provide a basis for challenging the Roman Catholic Church's authoritative interpretation of scripture. Likewise, textualism usually has the practical aim of upsetting existing interpretations of the Constitution. For example, Jus-

29. The discussion that follows is based on my discussion of the hermeneutics of the first amendment, although in the course of writing this piece my views have changed in some significant respects. See Solum, Freedom of Communicative Action: A Theory of the First Amendment Freedom of Speech, 83 Nw. L. REV. 54, 57-68 (1989).

30. H.-G. GADAMER, supra note 27 , at 154 (citation omitted). 
tice Hugo Black ${ }^{31}$ was challenging the authoritative interpretations embodied in the Supreme Court's own precedents when he made a textualist argument that when the first amendment says that Congress shall make "no law" abridging the freedom of speech, it means "no law."32

Even Martin Luther, however, would have to acknowledge that it is impossible to find a plain meaning for every individual passage in the Bible without the aid of some interpretive method. Some passages, if considered in isolation, are ambiguous or obscure. Likewise, the text of the Constitution of the United States is too indeterminate to be understood in isolation. To take Justice Black's example, what does "freedom of speech" mean? Similar questions can be asked about, among other terms, "due process of law," "equal protection," and "cruel and unusual punishments." The text of the Constitution is neither self-applying nor self-interpreting.

Protestant theological hermeneutics resolved the analogous problem of biblical interpretation with the device of the hermeneutic circle: ${ }^{33}$ the meaning of each individual passage of scripture is gleaned in light of the meaning of the Bible as a whole. "For it is the whole of scripture that guides the understanding of the individual passage: and again this whole can be reached only through the cumulative understanding of individual passages." 34 Likewise, it is a familiar maxim of both statutory and constitutional construction that individual passages must be construed in light of the meaning of the whole. Consider, for example, Justice Story's first recommendation for the construction of ambiguous constitutional provisions: "In construing the constitution of the United States, we are, in the first instance, to consider, what are its nature and objects, its scope and design, as apparent from the structure of the instrument, viewed as a whole, and also viewed in its component parts."35

In contrast to Protestant theology, which held that compre-

31. See generally Kalven, Upon Rereading Mr. Justice Black on the First Amendment, 14 U.C.L.A. L. REV. 428 (1967).

32. Cahn, Justice Black and First Amendment "Absolutes": A Public Interview, 37 N.Y.U. L. REV. 549, 553, 563 (1962).

33. The structure of the hermeneutic circle can be compared with John Rawls' notion of refiective equilibrium. See J. RAwLS, A THEORY OF JusTICE 48-51 (1971); Hoy, Hermeneutics, 47 SOC. RES. 449, 666 (1980).

34. H.-G. GADAMER, supra note 27 , at 154.

35. J. Story, Commentaries on the Constitution of the UNITEd STATES 136 (abridged ed. 1833). 
hension of plain meaning is the norm, with the ambiguity in particular passages resolved by reference to the meaning of the whole text, Schleiermacher begins with the premise that misunderstanding is the usual state of affairs, not only in scriptural interpretation, but in everyday conversation. ${ }^{36}$ For Schleiermacher, understanding a text or speech requires an understanding of the intentions of the author or speaker. The text must be placed in the context of the author's life and the history of the time in which it was written; Schleiermacher might say that the hermeneutic circle is expanded to encompass the context of history or of the situation that shaped the intentions with which the text was written. But because we lack direct access to the mental states of those with whom we converse or whose works we read, Schleiermacher contends that understanding is always problematic. ${ }^{37}$

Schleiermacher's theory bears a certain relationship to originalism. I do not want to claim that any originalist theory of constitutional interpretation requires contemporary interpreters to recapture the founders' own understanding of the Constitution in the same way that romantic hermeneutics does. Indeed, it is quite evident that sophisticated originalists make no such pretensions. I do think, however, that nonoriginalists have attacked originalism with arguments that assume that originalist constitutional interpretation has the same goal as does Schleiermacher's romantic hermeneutics: the interpreter (the judge) should discover the intention with which the text (the Constitution) was created or produced. In this sense, for Schleiermacher, interpretation is re creation or re production. ${ }^{38}$

Gadamer does not criticize Schleiermacher on the ground that intentions are irrelevant to interpretation. Rather, Gadamer observes that our understanding of original intent is necessarily conditioned by our own situation and concerns. Thus, our understanding of an author's original intent necessarily reflects our perspective. ${ }^{39}$

36. See G. WARNKE, supra note 27, at 11. For other accounts of Schleiermacher's hermeneutics, see H.-G. GADAMER, supra note 27, at 162-73; R. PALMER, supra note 23, at 84-97; J. BLEICHER, supra note 27, at 14-16. For Schleiermacher's own work, see generally F. SCHLEIERMACHER, HeRmeneutik (1959). My understanding of Schleiermacher is based on Gadamer, and when I use "Schleiermacher" in text, it might be more accurate to use "Schleiermacher as understood by Gadamer."

37. See H.-G. GADAMER, supra note 27, at 157.

38. See id. at 169.

39. See G. WARNKE, supra note 27 , at 25 . 
The basis of a Gadamerian argument for the impossibility of originalism (in the sense that originalism is understood on the model of romantic hermeneutics) is the same as the basis of my argument for the proposition that we are all originalists (in a sense different from the sense in which originalism is impossible). We can only understand the Constitution through the prejudices, prejudgments, and pre-understandings supplied by the tradition of interpretation in which we participate. That tradition includes the framing and ratification of the Constitution, but it includes much more than that. We are separated by two hundred years of history from the framing of the original provisions of the Constitution. More particularly, we have a long history of constitutional interpretation embodied in countless court decisions. In addition, our tradition includes many events outside the judicial arena that shape our understanding of the Constitution; the Civil War, the Great Depression, and the two world wars are examples. We are linked to the origins of the Constitution, but we are linked by a tradition. ${ }^{40}$ For this reason, we can never understand the Constitution in the same way that the framers and ratifiers understood it. To understand, says Gadamer, is to understand differently. ${ }^{41}$ (To understand the Constitution, I might add, is to understand it differently from the way that the framers and ratifiers did. $^{42}$ ) In this sense,

40. See Hoy, supra note 18 , at 497.

41. See H.-G. GADAMER, supra note 27 , at 264.

42. One defender of originalism who has attempted to answer this sort of criticism is Richard Kay, who has written an eloquent and well reasoned defense of originalism. Kay groups together a wide variety of arguments about the impossibility of originalism based on the assumption that all these arguments are based on the premise that the law is indeterminate. A footnote might seem to indicate that Kay believes that a Gadamerian argument shares this assumption. See Kay, supra note 9, at $238 \mathrm{nn} .54$ \& 55 . That belief (if Kay holds it) would be in error. The hermeneutic argument that I advance in the text does not presume that meaning is indeterminate in the sense that a reader can choose any meaning for a text; that we understand differently than did the framers does not entail that there are no limits on our understanding. Gadamer would argue that the tradition that links us to (and separates us from) the origin of the Constitution does, indeed, limit our interpretations. My own views on indeterminacy are similar to Kay's. See generally Solum, On the Indeterminacy Crisis: Critiquing Critical Dogma, 54 U. CHI. L. REv. 462 (1987).

Kay also addresses an argument that resembles Gadamer's in another portion of his article. Addressing the argument that "[o]ur world is drastically different from" the framers', he observes the fact that there is a well established discipline of history and that historians make claims to objective knowledge. Kay, supra note 9, at 252 . He then contends that such knowledge is made possible by the historian's "consciously suppressing" his "contemporary preconceptions and values." Id. Gadamer's response would be that if we could suppress our "preconceptions and values," we couldn't understand the Constitution at all: this is Gadamer's point about the enabling power of tradition. Kay 
originalism is impossible.

\section{Conceptions of Originalism}

At this point a defender of the distinction between originalism and nonoriginalism might contend that I have attacked the distinction at too high a level of abstraction. My claim that there is no distinction between originalist and nonoriginalist theories of constitutional interpretation has dealt only with the abstract concept of originalism. The defender of the distinction might argue that there are particular conceptions of originalism that are meaningfully different from particular conceptions of nonoriginalism. ${ }^{43}$ of course, in a sense this defense of the distinction is entirely correct. For example, if the conception of originalism was the theory that judges should decide a case as a majority vote of the Constitutional Convention would have decided the same case, and the conception of nonoriginalism was that judges should decide a case according to the criterion of efficiency, then the two theories would undoubtedly lead to different results and different opinions in particular cases. $\mathrm{My}$ attack on the distinction is premised on my evaluation of which conceptions of originalism and nonoriginalism are most plausible; my argument is that there is no meaningful distinction between plausible conceptions of originalism and nonoriginalism. Moreover, I contend that the forms of originalist theory that have emerged from the scholarly debate meet my criteria for a plausible conception.

Of course, there are many different conceptions of originalism at work in the originalism debate. Some versions of originalism are clearly implausible on theoretical grounds. ${ }^{44}$ I want to

might reply that we should only suppress our "contemporary preconceptions and values" leaving those prejudgments, preconceptions and pre-understandings that we share with the founders. But how are we to do this? For example, how are we to identify which preconceptions are contemporary ones? And what sort of understanding would, or could, we have, if we really could suppress our "contemporary preconceptions and values"? At this point, I will leave the debate for another day. In Kay's defense, I would note that he seems to have relied extensively on sources from debates in literary theory that present Gadamer's views in a very attenuated form.

43. For explications of the distinction between concepts and conceptions, see $\mathbf{R}$. DworkIN, supra note 17, at 70-72; J. RAWLs, supra note 33, at 7-10 (1971); Gallie, Essentially Contested Concepts, 56 Proceedings of THE ARISTotelian SocietY (1965).

44. For example, an originalist judge cannot possibly decide cases in exactiy the same way that a majority of the delegates to the Constitutional Convention would have decided them. We simply do not have enough information about the delegates, and the delegates did not have enough information about modern circumstances. 
focus on three particular conceptions of originalism that I think are plausible and representative of originalist approaches. The first conception emphasizes discovery of the general principles that animated the framing and ratification of the Constitution. The second conception posits the intentions of the framers as a definite description that picks out those events which do and do not meet the constitutional rule. The third conception emphasizes the practical role of evidence of the original intentions in deciding cases. None of these conceptions supports a meaningful distinction between originalist and nonoriginalist theories of constitutional interpretation. The first conception, the most plausible of the three, is also the conception that most clearly reveals the collapse of the distinction between originalism and nonoriginalism.

\section{A General Principles Conception of Originalism}

Michael Perry has observed that sophisticated originalists frame their theory in terms of general principles and not intentions in particular cases. ${ }^{45}$ Judge Robert Bork describes the originalist enterprise as follows: "The objection that we can never know what the Framers would have done about specific modern situations is entirely beside the point. The originalist attempts to discern the principles the Framers enacted, the values they sought to protect."46 Chief Justice Rehnquist takes a similar approach, ${ }^{47}$ and former Attorney General Meese writes: "Our approach understands the significance of a written document and seeks to discern the particular and general principles it expresses. It recognizes that there may be debate over the application of these principles. But it does not mean these principles cannot be identified." 48

Under this conception of originalism, the application of a provision of the Constitution to a particular case should be determined in light of the "value" or "principle" that prompted its adoption. But nonoriginalist theories of constitutional interpretation also seek general values and principles. Take, for example, Ronald Dworkin's view of constitutional interpretation. His mythical judge Hercules is to determine what "scheme

45. M. PERRY, supra note 13 , at $126-28$.

46. Bork, Original Intent and the Constitution, supra note 2, at 26; see also Bork, Economic Rights, supra note 2, at 826-27.

47. W. ReHnQuist, The SuPREMe Court 314-16 (1987).

48. Meese, The Battle for the Constitution, supra note 4, at 33. 
of principles has been settled" by the adoption of the Constitution. ${ }^{49}$ The judge, according to Dworkin, should look for the "conviction" that would have motivated the adoption of the Constitution. ${ }^{\text {so }}$ If both the originalist and the nonoriginalist are looking for "convictions," "principles," and "values" that prompted the adoption of the Constitution, what is the difference between what originalists and nonoriginalists do? At this point, the proponent of the distinction is required to provide us with an account of the difference between the general principles conception of originalism and similar nonoriginalist theories.

Michael Perry provides a specific and richly detailed nonoriginalist theory and provides a detailed defense of his claim that it differs from originalism. His theory emphasizes the analogy between constitutional interpretation and the interpretation of sacred texts:

In the American experience, the role of the constitutional text and the activity of interpreting the text have been very similar to the role of the sacred text and the activity of interpreting the text in the life of a religious community that is the steward of a living tradition. For the American political community, the constitutional text is not (simply) a book of answers to particular questions .... It is, rather, a principal symbol, perhaps the principal symbol, of fundamental aspirations of the tradition. ${ }^{51}$

In Morality, Politics, and Law, Perry claims that there is an important difference between the fundamental aspirations of our political community and the original principles and values that prompted the framing and ratification of the body of the Constitution and its amendments. Of course, there is a difference in terminology. Judge Bork, for example, refers to "the principles the Framers enacted, the values they sought to protect,"52 whereas Perry speaks of "the fundamental aspirations of the tradition."53 Perry claims that this difference in terminology refiects a real difference between original meaning and aspirational meaning.

But what is the difference between original meaning and

49. R. Dworkin, TAKING Rights Seriously 106 (1977).

50. See R. DworkIN, supra note 17 , at 365 .

51. M. PERRY, supra note 13 , at 139 (citation omitted).

52. Bork, Original Intent and the Constitution, supra note 2, at 26; see Bork, Economic Rights, supra note 2, at 826-27.

53. M. PERRY, supra note 13 , at 137 . 
aspirational meaning? I find two distinct answers to that question in Morality, Politics, and Law. The first answer is based on a spatial metaphor. Perry explains:

The referent of a text understood simply as evidence of past beliefs is, in a sense, "behind" the text. One must look behind the text, to the past beliefs, if one is to understand the text. The referent of a sacred text, however, is not "behind", but "in front of". One must respond to the incessant prophetic call of the text. One must recall and heed the aspirations signified by the text, and thereby create and give always-provisional, always-reformable meaning to the text. ${ }^{54}$

The question is whether Perry's metaphor of "behind" versus "in front of" for the difference between originalism and nonoriginalism expresses a real distinction.

Although I think I understand what Perry means when he says that the meaning of a sacred text or the Constitution is in front of the text and that original meaning is behind the text, I find it difficult to discern how Perry can claim that these qualities are mutually exclusive. On the one hand, it is quite clear that "aspirational meaning" is backward looking in the sense that Perry describes the relevant aspirations as aspirations of a tradition. Aspirational meaning is not divorced from the origins; it " is a mediation between past and present." "ss On the other hand, it is clear that a search for the original principles and values is forward looking in the sense that an originalist judge must seek what is relevant in those principles and values for the particular case given contemporary circumstances. Perry recognizes that originalists do not ask how the framers would have decided the particular case. Original meaning is also a mediation between past and present.

Perry gives a second account of the difference between aspirational meaning and original meaning that seems to focus on the way in which aspirational meaning can change. Perry observes that

the meaning of a [constitutional] provision can change in two basic ways. First, the meaning can become fuller, in the sense that as new cases arise, the meaning-what the aspiration requires-is further disclosed or specified. Second, the meaning can become different-that is, different for a particular person if she changes her mind as to what the aspiration

54. Id. at 137-38 (citation omitted).

55. Id. at 138 (quoting D. Tracy, The Analogical Imagination 99 (1981)). 
requires. $^{56}$

Presumably, Perry intends to contrast this picture of change in aspirational meaning with the static quality of original meaning. But it is difficult to discern what Perry has in mind. Surely, original meaning changes in the first sense of becoming fuller: our understanding of the purposes and intentions of the framers is disclosed or specified by their application to specific cases.

It should also be clear by now that the original meaning must also change in the sense that it becomes different. Recall Gadamer's aphorism: to understand is to understand differently. More concretely, an originalist judge can change her mind about what the original principles and values require in a particular case. Indeed, as new circumstances prompt us to ask new questions about what the original meaning is, it is inevitable that our understanding will change.

Perry has not given us a satisfactory account of the difference between original meaning and aspirational meaning. I think that there is a reason for Perry's inability to articulate the difference. The meaning of the Constitution, whether we call it aspirational meaning or original meaning, is only given to us in the process of application. David Hoy has made this point in response to Perry. Hoy's own critique of the distinction between originalism and nonoriginalism emphasized an important aspect of Gadamer's thinking that I have not yet made explicit. For Gadamer, the distinction between understanding a text and applying it is an artificial one. To understand a text is already to apply it. Therefore, to understand a text is to understand it differently as it is applied in new situations. Hoy demonstrates that Perry's account of the contrast between originalism and nonoriginalism relies on a picture of interpretation as a two-step process. Perry's picture is that the first step is to understand the meaning of a text and the second distinct step is to apply the text. ${ }^{57}$

Gadamer has given a detailed and persuasive critique of the two-step view. Indeed, Gadamer uses the example of legal interpretation to undermine the two-step process view of interpretation: Gadamer argues that in order to understand a text, we must apply it (at least imaginatively). ${ }^{58} \mathrm{I}$ will not attempt to

56. Id. at 140 (emphasis in original).

57. See Hoy, supra note 18 , at 493-94.

58. H.-G. GADAMER, supra note 27 , at 289-305. 
duplicate Gadamer's full argument here, but I do think that the actual practice of judges, lawyers, and legal scholars trying to understand legal texts supports his critique. For example, think of the pervasive role of cases, both actual cases and hypothetical cases, as tools for understanding the law. Now try to imagine understanding a constitutional provision, without any knowledge of cases and without any ability to apply the provision imaginatively to hypothetical cases. The point of this exercise is to bring out the importance of application in understanding. If Gadamer is correct, then the two-step picture of interpretation is wrong, yet Perry's argument for the contrast between originalism and nonoriginalism depends on that picture.

When Perry portrays originalism, he paints in faint grays and browns; the originalist discovers the intentions of the framers and ratifiers in the abstract, without application to a particular case entering into the picture. But when Perry portrays nonoriginalism he uses a rich and varied palette; nonoriginalist meaning grows and changes in response to the infinite variety of particular applications. Once we reformulate originalism without the two-step picture of originalist interpretation, it is the distinction between originalism and nonoriginalism that begins to fade. An originalist judge who seriously attempts to apply original principles and values to new situations will inevitably engage in the same process as a nonoriginalist. I give some supporting evidence for this point in Part II, when I argue that, as a practical matter, Chief Justice Rehnquist employs the same method of constitutional interpretation as Justice Brennan.

\section{A Definite Description Conception of Originalism}

Perhaps at this point, the originalist will object that I have formulated too weak a version of originalism. By focusing on a general principles conception, I have made the original meaning itself something that must be interpreted rather than simply applied. Another group of originalists is fond of referring to the intention of the framers. ${ }^{59}$ They believe that we can often (not always, of course) discover the intention that motivated the adoption of a particular constitutional provision, and then use the intention of the provision as a guide to the decision of cases.

These originalists - by referring to "the intention"- com-

59. See Kay, supra note 9, at 231 (using "the intention"); id. at 243 (using "a single intention"). 
mit a fallacy of reification by treating the various mental states that accompany an action, in this case the complex actions of many actors that constitute the framing and ratification of the Constitution and its amendments, as an entity or abstract object. Because the use of the definite article "the" in conjunction with the general term "intention" suggests that these originalists are employing a singular term (a term that picks out one and only one object), I call this view the definite description conception of originalism. ${ }^{60}$ Originalists who use the phrase "the intention of the framers" seem to have a picture of the nature of intentions that has a bewitching effect on their views about constitutional interpretation. I want to attack the picture of intentionality that leads to talk about "the intention of the framers," but in order to do so, I need to make the picture more precise than these originalists themselves usually do. If the framers had something that can be called "the intention" of a particular constitutional provision which can be applied to particular cases in a way that constrains outcomes, I think it is most plausible to conceive this thing as an authoritative expression of the description under which the framers and ratifiers intentionally acted in adopting the provision. This canonical formulation would consist of a description under which the action of framing and ratifying the Constitution was intended.

This description could be used to distinguish those applications of the provision that are compatible with the framers' wishes and those that are not. In the vocabulary of philosophers of language, it would have an extension. Thus, a plausible candidate for the intention of the framers with respect to the fourteenth amendment equal protection clause might be expressed as follows: They intended to outlaw state discrimination against the former slaves and their descendants. Future applications of the clause are consistent with the intention of the equal protection clause if they fall under the description "inequality of the races with respect to important legal rights," but such applications are inconsistent with the intention if they cannot be so described.

The definite description conception fails because evidence of the framers' intentions cannot give us the intention of the framers in a particular case; their intentions will never fall under a

60. I employ the terms "definite description" and "singular term" as they are used by philosophers of language. See R. Martin, The Meaning of Language 133 (1987). 
definite description. The evidence will always support a variety of formulations of the framers' intentions. There is a fundamental reason for this that is most precisely expressed in the terminology of philosophy of language: A sentence expressing an intention is an intensional context and not an extensional context. $^{61}$ Roughly, this means that the truth of statements about our intentions depends on the descriptions we use in those statements. I can intend an action (the set of physical occurrences that makes up the event referred to as the action) if it is described one way, but not intend the very same action (the physical occurrences) if it is described differently. For readers unfamiliar with this terminology, I have provided some further explanation and examples in a footnote. ${ }^{62}$ The basic point is that the truth of the expression "I intended X" depends on the description that is substituted for the variable $X$ in the expression.

The dependence of the truth of statements about intentions on the descriptions used has important implications for the originalism debate. Let me illustrate with an example Ronald

61. Notice that "intention" and "intension" are different terms with very different meanings. There is a large body of philosophical literature on extensional and intensional contexts. The distinction has its origin in Frege's distinction between sinn and bedeutung, or "sense" and "reference." Some philosophers express the same distinction with different terminology, using "opaque" for "intensional" and "transparent" for "extensional." See generally W. QUINE, WORD AND OBJECT (1960). For a recent introduction to this basic distinction, see R. MARTIN, supra note 60, at 143-49, 177-89; see also M. DEVITT \& K. STERELNY, LANGUAGE AND REALITY (1987).

62. The following examples illustrate the difference between the intensional and extensional contexts. Statements that attribute factual predicates to objects are extensional contexts: for example, " $\mathrm{X}$ is 35 years old" is an extensional context. This means that we can substitute any expression or description that refers to the same person for $\mathrm{X}$ without affecting the truth value of the sentence. The person to whom the expression refers is called its "extension." Thus, if my postman is my eldest brother and if "My postman is 35 years old," is a true statement, then "My eldest brother is 35 years old" will also be true. Furthermore, it will be true even if I don't know that my older brother is my postman. On the other hand, statements of intentions are not extensional contexts. For example, if I say, "I intended to miss the surprise birthday party for X," the truth of the statement may depend on which of one or more descriptions is given for $\mathrm{X}$, even if the descriptions all refer to the same person. Suppose that my postman is my eldest brother, but that I am not aware of that fact because we are orphans who have been separated since childhood. It may be the case that " $I$ intended to miss the surprise birthday party for my postman" is true. Under the description "the surprise birthday party for my postman," my missing the party was intentional. But under the description, "the surprise birthday party for my eldest brother," the same action-my missing the party-was not intentional. The two descriptions refer to the same event, the party for the person who is both my eldest brother and my postman, but substitution of extensionally equivalent descriptions can change the truth value of an intensional context that contains them. 
Dworkin has used. ${ }^{63}$ Suppose that the framers of the equal protection clause of the fourteenth amendment had an intention to prohibit any event that would fall under the description "inequality of the races with respect to important legal rights." Take a particular case in which black children in Kansas in 1954 were legally required to attend segregated schools. Suppose that we conclude that this case can be described as one that falls under the description "inequality of the races with respect to the important legal right to education." We then would conclude that the intention of the framers would support a decision that the segregation was unconstitutional. Suppose, however, that the framers did not have an intention to prohibit events that fall under the description "separate schools for black and white children." We might conclude that this description also applies to the case at hand. Thus, we seem to reach the conclusion that the intention of the framers leads in two different directions. This result does not mean that the framers' intentions were self-contradictory. Given their beliefs about the world, the two statements of intention were likely consistent: for example, they may have believed that education was not an important legal right, whereas we believe that it is.

The next step of the argument is to make explicit the observation that one can intend the same action under a wide variety of descriptions, and that these descriptions can vary along a number of dimensions, including generality versus particularity. For example, the intention of the equal protection clause can be formulated either abstractly, such as an intention to ensure equal treatment on matters of fundamental justice, or more particularly, such as an intention to prohibit particular legal disabilities imposed on the former slaves following the Civil War. Indeed, with respect to most constitutional provisions, the evidence will usually support the inference that the framers and ratifiers acted intentionally under innumerable descriptions. The point is this: No single description can fully express the intention of the framers.

At this point, it is clear that the definite description conception of originalism cannot succeed. It assumes that an intention can be formulated as a single description with a definite extension. But for that to be true, statements of intention would have

63. See R. Dworkin, supra note 17 , at 362 . (Dworkin's argument is similar to the one made here.) 
to be extensional contexts. We know, however, from an examination of ordinary linguistic practice that expressions of intention are intensional contexts and not extensional contexts. Further, we know that the action of framing or ratifying a constitutional provision was probably intentional under a variety of more and less general or particular descriptions. Therefore, we know that there is no single description that expresses the intention of a particular constitutional provision.

Let me disavow some possible misinterpretations of my argument. I am not claiming that intentions do not exist; I am claiming that a certain picture of intentionality is misleading. I am not claiming that our knowledge about the motives, hopes, and expectations of the framers and ratifiers is irrelevant to the process of constitutional interpretation. Our knowledge of the origins of the Constitution is not only relevant, it is sometimes profoundly important. I am not claiming that because intention expressions are intensional contexts, it follows that in every constitutional case, evidence about the framers' and ratifiers' intentions will support points in different directions. In many cases, evidence concerning intentions will provide support for a particular result. The purpose of this section is only to argue against the definite description conception of originalism. ${ }^{64}$

\section{A Practical Procedures Conception of Originalism}

There is another conception of originalism that the defender of the distinction might argue will support a meaningful contrast to nonoriginalism. Originalism could be conceived of as a practical prescription for judicial method. In deciding cases and writing judicial opinions, originalist judges should limit their attention to evidence of the intentions of the framers and ratifiers of the particular constitutional provision at issue. Nonoriginalism does not observe this limitation. Nonoriginalist judges, depending on the particular nonoriginalist theory at issue, ought to consult political philosophy, economics, or contemporary moral standards when they interpret the Constitution. Thus, the

64. If the definite description conception were viable, that would support a certain distinction between originalism and nonoriginalism. My point about the ubiquity of originalism, see supra Part I-A, would still have force, however. When it came to formulating and applying the definite description, we would still be pervasively influenced by the tradition that links us to (but separates us from) the framers and ratifiers, but one could still maintain that a constitutional practice limited to the discovery and application of such definite descriptions would be different from a nonoriginalist practice that was not so limited. 
argument concludes, there is a practical difference between originalism and nonoriginalism, even if it is not grounded in a general theory of interpretation.

In Part II, I meet this defense of the originalism/ nonoriginalism distinction head on, and argue that in the actual practice of constitutional interpretation, there is no such difference between self-professed originalist and nonoriginalist judges. But before I give the evidence for this empirical refutation, I want to note that this practical version of the originalism/ nonoriginalism distinction does not in any real way deflect the theoretical criticism offered in this Part of the Essay. Consider a judge who seeks to decide cases by using this practical version of originalism. Such a judge will attempt to focus on the original meaning of the provision, by studying the text, remarks made at the Constitutional Convention, the Federalist Papers, the historical practice of the founding generation, and so forth. Will this effort result in an exclusion of the influence of considerations suggested by the intervening traditions, the history, the precedents, the ideas of political philosophy, economics, or contemporary morality to which the nonoriginalist gives explicit attention? Of course not. No sophisticated originalist would claim that such considerations will not pervasively shape the originalist judge's understanding of the text. Originalist opinion writing cannot guarantee originalist decisionmaking.

It is certainly the case that some judicial opinions seem to reflect an originalist methodology; these opinions carefully recite the history of the particular provision being interpreted and quote the writings or speeches of the framers and ratifiers. But no matter how carefully a judge attempts to limit her attention to evidence of the original intent, she cannot escape the tradition that shapes her understanding of what that intent means when it is applied to a particular case. As a practical strategy for deciding cases and writing opinions, originalism cannot eliminate the problem of the interpreter being situated within a tradition that pervasively shapes pre-understandings, preconceptions, and prejudices.

\section{DISREGARD OF THE ORIGINALISM/NONORIGINALISM Distinction in Practice}

Thus far, my discussion has focused on interpretation theory, but my point about the collapse of the originalism/ nonoriginalism distinction can be made in very practical terms. 
Judges of all sorts and especially Justices of the United States Supreme Court know (at least tacitly) that there is no fundamental distinction between originalism and nonoriginalism. When one examines the actual practice of constitutional interpretation, it becomes quite clear that self-professed originalists, like Chief Justice Rehnquist, do not always (or even frequently) adhere to originalism as a practical strategy for deciding cases and writing opinions. Similarly, self-professed nonoriginalist judges, like Justice Brennan, view evidence of original intent as profoundly relevant to the task of constitutional interpretation.

Fundamentally, my argument that the originalism/ nonoriginalism distinction is ignored in practice must rely on an appeal to the experience of readers familiar with constitutional practice. ${ }^{65}$ I certainly am not going to attempt a grand survey of all the constitutional decisions of the Supreme Court in order to demonstrate my point statistically. To make my claim plausible, however, I will offer some examples of the practical unimportance of the originalism/nonoriginalism distinction.

Chief Justice William Rehnquist has advocated originalism in his extrajudicial writings ${ }^{66}$ and has relied on originalist premises in his opinions for the Court. ${ }^{67}$ But Rehnquist has also written opinions that seem flatly to contradict many of the premises of originalism that are incompatible with nonoriginalism. One example is his opinion for the Court in Dames \& Moore $v$. Regan. ${ }^{68}$ At issue was the validity of various unilateral actions taken by the President in the settlement of the Iranian hostage crisis. The first reason for believing that Rehnquist's decision in Dames \& Moore does not adhere to a narrow vision of originalism is that his opinion never mentions the views of the framers or ratifiers of the Constitution concerning the unilateral power of the President in foreign affairs. This omission is not surprising in light of the historical evidence. Leonard Levy has con-

65. Another source of confirmation is the judgment of scholars who have studied the Supreme Court. For example, Leonard Levy, the eminent historian, writes:

Originalists in Reagan's Department of Justice and on the federal courts insisted on a return to the pristine meanings of 1789 , but never with respect to executive powers.... Rehnquist and Bork, who are so tight with rights that they require them to be specified and familiar before according them recognition, are extravagant in recognizing inherent as well as implied executive powers.

L. LEVY, supra note 12, at 394.

66. See Rehnquist, supra note 3.

67. See Wallace v. Jaffree, 472 U.S. 38,49 (1985).

68. 453 U.S. 654 (1981). 
vincingly argued that the framers envisioned a role for the President that is narrower than the one authorized by Dames \& Moore ${ }^{69}$ In addition to the history Rehnquist does not use, there is a second reason to see his opinion as nonoriginalist-the history he does use. Rehnquist's opinion emphasizes historical developments that occurred long after the last member of the founding generation had departed. By relying on evidence that Presidents have frequently taken extraordinary measures to settle claims by other nations against the United States and that frequently Congress has not objected to these measures, ${ }^{70}$ Rehnquist is implicitly acknowledging that our whole tradition is relevant to the interpretation of the Constitution. It is not only the origin but also the subsequent history of the Constitution that shapes our understanding of its meaning.

Justice William Brennan may be considered the paradigmatic nonoriginalist judge. He has written a theoretical defense of nonoriginalist constitutional interpretation ${ }^{71}$ and has been the implied target of originalist criticism of the Supreme Court. Nonetheless, Justice Brennan is the author of opinions that display a profound regard for the concerns and purposes of the framers and ratifiers of the Constitution. Perhaps the most famous example is New York Times Co. v. Sullivan. ${ }^{72}$ Brennan's opinion for the Court took aim at the settled contemporary understanding of the first amendment freedom of speech-that private actions for libel are not limited by the constitutional guarantee. ${ }^{73}$ Brennan focused on early historical practice as a guide to the meaning of freedom of speech. The Alien and Sedition Acts prompted the founding generation to reflect on the meaning of the first amendment; the understanding that emerged was that a free government could not be defamed by its citizens. ${ }^{74}$ Brennan used the understanding developed by the framers and their contemporaries as the basis for upsetting the interpretation that had been taken for granted for many decades.

69. See L. LEVY, supra note 12, at 30-53.

70. Dames \& Moore, 453 U.S. at 679-83.

71. Brennan, supra note 7; see also Abington School Dist. v. Schempp, 374 U.S. 203, 237 (1963) (Brennan, J., concurring) (warning that "too literal [a] quest for the advice of the Founding Fathers" is likely to be "futile").

72. 376 U.S. 254 (1964).

73. See Beauharnais v. Illinois, 343 U.S. 250 (1952) (holding that group defamation is not protected); Chaplinsky v. New Hampshire, 315 U.S. 568, 572 (1942) (containing dictum to the effect that libel is not protected by the first amendment).

74. Sullivan, 376 U.S. at 272-74. 
Less prominent than Sullivan, but perhaps even more telling, is Justice Brennan's dissenting opinion in Atascadero State Hospital v. Scanlon. ${ }^{75}$ Justice Brennan took on a longstanding interpretation of the eleventh amendment to the Constitutionthat the amendment constitutionalizes a principle of state sovereign immunity against suit in federal court. That interpretation is usually assumed to have prevailed since the 1890 decision of the Supreme Court in Hans v. Louisiana. ${ }^{76}$ As in Sullivan, Brennan's argument for a change in settled doctrine relied on an appeal to the original understanding. The eleventh amendment, Brennan argued, was not intended to constitutionalize sovereign immunity. Rather, the amendment had a more limited purpose-to nullify judicial construction of the state-citizen diversity clause of article III as an independent basis for allowing suits against a state by citizens of another state without the consent of the state being sued. This argument was supported with pages and pages of detailed historical analysis. ${ }^{77}$ Brennan's Atascadero dissent is another classic example of originalism: once again, the original understanding is used as the wedge to undermine the contemporary interpretation.

Not surprisingly, the eleventh amendment has also elicited one of Justice Rehnquist's more starkly nonoriginalist decisions. In lone dissent in Nevada v. Hall, ${ }^{78}$ Justice Rehnquist took the position that the concept of sovereignty which underlies article III and the eleventh amendment should give rise to an implied constitutional sovereign immunity principle that is binding on state as well as federal courts. ${ }^{79}$ Justice Rehnquist's argument in Nevada v. Hall is a close cousin to Justice Douglas's argument in Griswold v. Connecticut, ${ }^{80}$ usually branded by originalists as a nonoriginalist opinion. In Griswold, Justice Douglas, writing for the Court, relied on a constitutional right of privacy that was not enumerated in any particular provision, but was arguably implicit in several amendments, including the first, third, fourth, fifth, and ninth. ${ }^{81}$ Likewise, in Nevada v. Hall, Justice Rehn-

75. 473 U.S. 234, 297-302 (1985) (Brennan, J., dissenting).

76. 134 U.S. 1 (1890). It is a matter of some controversy whether this doctrine actually was announced in Hans, but the resolution of that question and many other intricacies of eleventh amendment doctrine are well beyond the scope of this Essay.

77. Atascadero State Hosp., 473 U.S. at 259-90.

78. 440 U.S. $410,432-43$ (1979) (Rehnquist, J., dissenting).

79. Id. at 439 .

80. 381 U.S. 479 (1985).

81. Id. at $482-85$. 
quist's dissent relied on a constitutional principle of sovereign immunity that is not enumerated in any particular provision, but was implicit in several provisions, including the eleventh amendment.

Of course, my examples of the practical unimportance of the distinction between originalism and nonoriginalism do not demonstrate that the distinction could not be maintained..$^{82}$ Judges may simply choose the method of interpretation that supports the results they prefer. For that reason, the argument of this Part of the Article depends for its force on the theoretical arguments that are advanced in Part I. But the similarities between self-professed originalists and nonoriginalists in practice suggests that it is plausible to believe that they are not so far apart in theory. Both Brennan and Rehnquist are doing what any interpreter of the Constitution must do; they are interpreting the Constitution under the influence of both the origin of the Constitution and the tradition that links us to (but separates us from) that origin.

What then does account for the differences between Brennan and Rehnquist? In a sense, Michael Perry has the answer when he insists (in an only slightly different context) on the priority of the particular. ${ }^{83}$ Perry's point is about the priority of the particular in moral reasoning: it is our considered judgments about particular cases and not our grand moral theories that guide ethical life. Brennan and Rehnquist passionately disagree about the meaning of constitutional principles such as freedom of speech or federalism in particular cases, but their seeming disagreement about the proper method of constitutional interpretation is the symptom and not the cause of their real differences. Judges understand the meaning of the Constitution by applying it to particular cases.

82. These examples do demonstrate that there is a practical sense in which there is a distinction between originalism and nonoriginalism. The conception of originalism as a practical procedure is discussed above; correspondingly, one can practice constitutional interpretation without explicitly referring to intentions of the framers and ratifiers. In Part I, I argued that a mere difference in styles of opinion writing does not mean that there is a real difference in the way origins shape outcomes. For example, Justice Rehnquist could undoubtedly give an originalist defense of Nevada v. Hall; he would argue that the principle of sovereign immunity is implicit in the structure of the Constitution itself, and that such concerns were very much in the minds of the framers and ratifiers.

83. M. PERRY, supra note 13 , at 35 . 


\section{ORIGINALISM AND PROPHECY}

Michael Perry defends what he calls a nonoriginalist theory of constitutional interpretation. Perry believes that for the originalist, the constitutional text has a static meaning; for the nonoriginalist, however, "the constitutional text plays an important 'prophetic' role: incessantly disturbing the political community." 84 Perry has a very sophisticated theory, and his development of the analogy between constitutional interpretation and the prophetic interpretation of sacred texts captures something essential about the practice of constitutional law. But Perry fails to appreciate one of the most important characteristics of his own theory. Indeed, the feature that Perry sees as most important in his theory-the ability of constitutional prophecy to disturb-is what makes Perry the constitutional theorist who can most accurately be called originalist in the only sense that it is possible to be one. In that sense, however, Perry's theory is not a method that judges can choose to use or to discard; his theory describes what judges must do when they interpret the Constitution.

The ability of constitutional prophecy to disturb is in a very important sense related to the role of the Constitution as the "origin" of our political tradition. In this sense, the analogy between constitutional interpretation and the prophetic interpretation of religious texts brings out the most profound truth in the concept of originalism. Stanley Cavell expressed this point as follows:

The internal tyranny of convention is that only a slave of it can know how it may be changed for the better, or know why it should be eradicated. Only masters of a game, perfect slaves to that project, are in position to establish conventions which better serve its essence. This is why deep revolutionary changes can result from attempts to conserve a project, to take it back to its idea, keep it in touch with its history. To demand that the law be fulfilled, every jot and tittle, will destroy the law as it stands, if it has moved too far from its origins. Only a priest could have confronted his set of practices with its origins so deeply as to set the terms of Reformation. ${ }^{85}$

Jefferson Powell has made a similar point with respect to the text of the Constitution. He expresses the potential of the

84. Id. at 136.

85. S. Cavell, The Claim of Reason 120-21 (1979). 
Constitution to disturb as its "revolutionary role."86 Powell puts it this way:

Just as in a scriptural religion, the most elaborate and established theological system can be challenged by the call ad fontes ("back to the sources"); so in American constitutional law it is always possible to go back to the text, to challenge what currently is in the name of what once was written. Neither decades of popular acquiescence nor an unbroken string of Supreme Court decisions can insulate a governmental practice from such a challenge. ${ }^{87}$

Because the Constitution is our origin, it has the potential to disturb our practice. Just as Martin Luther initiated the transformation of religious practice by confronting the Church with its origins, so, too, the text of the Constitution and evidence of its original meaning can serve as the linchpin of a transformative politics.

So far, I have argued that origins in general and the text of the Constitution in particular can serve what Perry calls a prophetic function. The next step in my argument is to demonstrate that the original intentions of the framers and ratifiers also have potential to disturb our constitutional practice. To begin this demonstration, I want to confront the theory of originalism with its own origins. The source of the idea that a legal text should be interpreted in light of the intentions of its author is Aristotle's discussion of equity in the Nichomachean Ethics. "Our next subject is equity and the equitable, and their respective relations to justice and the just," Aristotle begins. ${ }^{88}$

What creates the problem is that the equitable is just, but not the legally just but a correction of legal justice. The reason is that all law is universal but about some things it is not possible to make a universal statement which will be correct. In those cases, then, in which it is necessary to speak universally, but not possible to do so correctly, the law takes the usual case, though it is not ignorant of the possibility of error. ... When the law speaks universally, then, and a case arises on it which is not covered by the universal statement, then it is right, when

86. Powell, Parchment Matters: A Meditation on the Constitution as Text, 71 IowA L. REV. 1427, 1433 (1986).

87. Id.

88. ARISTOTLE, Nichomachean Ethics in THE COMPLETE WORKS OF ARISTOTLE 1137a (J. Barnes ed. 1984) (Following the standard practice, I have given pagination to the Bekker edition of the Greek text of Aristotle of 1831. Thus, 1137a refers to the first column of page 1137 of the Bekker edition.) 
the legislator fails us and has erred by over-simplicity, to correct the omission-to say what the legislator himself would have said had he been present, and would have put into the law if he had known. ${ }^{89}$

Of course, two millennia of practice have sharpened our understanding of the role of intentions in adjudication; Aristotle's account now sounds quaint in some respects. His account, however, has had a profound influence on this history of the interpretation of legal texts. ${ }^{90}$

It is no accident that at the origin of the "framers' intent" idea, we also find the idea of equity-of doing justice in the particular case, despite the letter of the law. Originalist theorists may take strong exception to the idea that judges should "do equity" when they interpret the Constitution, but historically judges have long appealed to the intentions of the authors in order to support an equitable construction. There is a close connection between the nonoriginalist notion that the Constitution should be viewed as a charter establishing justice, and the originalist notion that the Constitution must be interpreted to advance the fundamental principles and values of the framers and ratifiers.

The prophetic or disturbing function of originalism can also be illustrated by recalling Justice Brennan's use of history in New York Times Co. v. Sullivan. ${ }^{91}$ His opinion draws on the framers' and ratifiers' understanding of the freedom of speech, crystallized by the Alien and Sedition Acts, in order to take us back to the fundamental aspiration or central meaning of the first amendment. Importantly, this view of the transformative potential of originalism for social change is recognized by the conservative proponents of originalism. For example, former Attorney General Meese observed,

When the Supreme Court, in Brown v. Board of Education, sounded the death knell for official segregation in the country, it earned all the plaudits it received. But the Supreme Court in that case was not giving new life to old words, or adapting a "living," "flexible" Constitution to new reality. It was restoring the original principle of the Constitution to constitutional

89. Id. at $1137 \mathrm{~b}$.

90. See, e.g., Riggs v. Palmer, 115 N.Y. 506, 510, 22 N.E. 188, 189 (1889) (citing Aristotle in support of equitable construction of the Statute of Wills). There is a large body of case law dealing with the "equity of the statute." See 2A SUTHERLAND ON STATUTORY CONSTRuCTION 54.01-08 (N. Singer ed. 1984).

91. 376 U.S. 254 (1964). 
law. ${ }^{92}$

Perry takes Brown v. Board of Education ${ }^{93}$ as a paradigm case of the sort of nonoriginalist interpretation that he advocates in opposition to Meese's originalism. ${ }^{94}$ My point is that Perry's theory is, in an important sense, an originalist one.

In the end, I think both originalists and nonoriginalists are after the same thing when they interpret the Constitution. They seek the truths that the Constitution conveys to us. When we interpret the Constitution, we look for a practical plan of government and for protection of fundamental rights. Originalism reminds us that constitutional truths can lie dormant; the originalist insists that we pay close attention to what the framers said when we try to discover the constitutional truth about what plan is practical and what liberties are fundamental. The original meaning sometimes plays a crucial role in disrupting our current practice. Originalist constitutional interpretation is sometimes transformative politics. The nonoriginalist points out that in our search for constitutional truth, we cannot ignore our own beliefs about what is practical and what is truly fundamental. Both the originalist and the nonoriginalist are right: we cannot escape the history that links us to and separates us from our origins.

92. Meese, The Battle for the Constitution, supra note 4, at 34 .

93. 349 U.S. 294 (1954).

94. M. PERRY, supra note 13 , at 167. 

" 